\title{
Heralds of Change: In the Aftermath of Skanska (C-724/17) and Sumal (C-882/19)
}

\section{Benedikt Freund}

Accepted: 18 January 2022 / Published online: 15 February 2022

(C) The Author(s) 2022

\begin{abstract}
The Court of Justice of the European Union (CJEU) can be placed at the origins of the pan-European awakening of private enforcement of EU competition law. The CJEU has, in a steadfast and unwavering manner, advocated for the rights of victims of competition law infringements, elevating cartel damages proceedings from a rare sight to a well-established phenomenon. In its judgment Vantaan kaupunki v. Skanska Industrial Solutions Oy and others (Skanska), the CJEU ruled that the circle of persons liable for the harm resulting from an anticompetitive behaviour is to be determined according to the concept of undertaking as referred to in Art. 101 of the Treaty on the Functioning of the European Union (TFEU). In Sumal v. Mercedes Benz. Trucks Espana (Sumal) the Court clarified under which circumstances distinct legal entities within a group of companies form one single undertaking and are thus to be made the defendant in cartel damages proceedings. The CJEU's judgments in Skanksa and Sumal mark a certainly provisional climax in the evolution of private enforcement of EU competition law. This article aims to depict the conceptual backbone of both judgments and to explore possible consequences in regard to liability within groups of companies.
\end{abstract}

Keywords Private enforcement · Notion of undertaking - Skanska S Sumal . Liability within a group of companies

B. Freund $(\bowtie)$

MLaw, Attorney-at-Law, Doctoral Candidate at the University of Zurich, Zurich, Switzerland e-mail: Benedikt.Freund@kellerhals-carrard.ch

Present Address:

B. Freund

Kellerhals Carrard, Zurich, Switzerland 


\section{Introduction}

The Court of Justice of the European Union (CJEU) can be placed at the origins of the pan-European awakening of private enforcement of EU Competition Law. The CJEU has, in a steadfast and unwavering manner, advocated for the rights of victims of competition law infringements, elevating cartel damages proceedings from a rare sight to a well-established phenomenon. ${ }^{1}$ In its judgment Vantaan kaupunki $v$. Skanska Industrial Solutions Oy and others ${ }^{2}$ (Skanska), the CJEU ruled that the circle of persons liable for the harm resulting from an anticompetitive behaviour is to be determined according to the concept of undertaking as referred to in Art. 101 of the Treaty on the Functioning of the European Union (TFEU), rather than the Member State's domestic legal system. Thus, the concept of undertaking is of uniform meaning in both public and private enforcement of EU competition law.

As the concept of undertaking has until now mainly been applied in public enforcement, new questions have been and will be triggered, many of which would not have surfaced as such in public enforcement. This fact is confirmed by the preliminary ruling of the CJEU in Sumal v. Mercedes Benz Trucks Espana ${ }^{3}$ (Sumal). The Court clarified under which circumstances distinct legal entities within a group of companies form one single undertaking and are thus to be made the defendant in cartel damages proceedings - i.e. the Court gave guidance on how to determine liability for damages caused by competition law infringements. Both judgments Skanksa and Sumal - mark a certainly provisional climax in the evolution of private enforcement of EU competition law. This article aims to depict the conceptual backbone of both judgments and to explore possible consequences in regard to liability within groups of companies.

\section{Applying the Concept of Undertaking Beyond Public Enforcement - SKANSKA (C-724/17)}

\subsection{Facts}

At the core of the preliminary judgment is an action for damages of the Finnish city of Vantaa seeking compensation from several companies. These companies, in turn, were successors of several other companies that had partaken in a Finnish asphalt cartel. Said cartel had been discovered and sanctioned by the Finnish competition authority in 2004. The sanction had been ultimately upheld by the administrative court of last instance in 2009. ${ }^{4}$ All of the companies against which the city of Vantaa brought an action for damages had previously acquired shares in one of the companies which had participated in the infringement. The infringers were

\footnotetext{
1 See for a comprehensive overview, Laborde (2021), p. 232 et seq.

2 CJEU, C-724/17, Skanksa Industrial Solutions, EU:C:2019:204.

3 CJEU, Case C-882/19 Sumal v. Mercedes Benz Trucks Espana, EU:C:2021:800. For the headnotes to this decision see this issue of IIC at https://doi.org/10.1007/s40319-022-01151-4.

${ }^{4}$ CJEU, C-724/17, Skanksa Industrial Solutions, EU:C:2019:204, at para. 24.
} 
dissolved either before or after acquisition. As the economic activities of the infringing companies were not discontinued by the acquirers, the Finnish competition authority, by applying the economic continuity test, qualified the acquirers as undertakings responsible for the infringement.

The referring court had doubts as to whether the city of Vantaa could seek damages from the acquiring companies as the infringing companies had already been dissolved. The Finnish court opined that, according to its national civil law, a person was not to be held liable for damages resulting from anticompetitive conduct even though compensation could not be obtained from the dissolved companies. In sum, the CJEU had to determine whether the circle of persons liable to compensate the harm resulting from anticompetitive behaviour is to be determined according to national, i.e. Finnish law, or in accordance with the concept of undertaking as stipulated by the TFEU.

\subsection{Judgment}

The CJEU addressed the matter by pointing out the direct effect of Arts. 101 and 102 TFEU among individuals. ${ }^{5}$ Further, the Court reiterated, that these provisions confer directly applicable rights such as the right to damages. ${ }^{6}$ Where there is a causal relationship between the harm and the anticompetitive conduct, any person has the right to claim compensation. If that were not the case, the full effectiveness of Art. 101 TFEU would be at risk. ${ }^{7}$

Further, two sets of rules governing the right to compensation were distinguished. The first set concerns rules which are put forth by EU law, whereas the second set concerns rules that are governed by the domestic rules of the Member States, provided that they respect the principles of equivalence and effectiveness. ${ }^{8}$ According to the Court, the question regarding the circle of persons liable to compensate falls under the first set of rules. In consequence, EU competition law directly determines the person liable for harm caused by infringements of Art. 101 TFEU. $^{9}$

When determining the circle of persons liable for an infringement, the Court heavily relied on the Opinion of Advocate General (AG) Wahl. ${ }^{10}$ According to AG Wahl, the circle of persons liable for harm caused by anticompetitive behaviour is

\footnotetext{
5 CJEU, C-724/17, Skanksa Industrial Solutions, EU:C:2019:204, at para. 25.

${ }^{6}$ CJEU, C-724/17, Skanksa Industrial Solutions, EU:C:2019:204, at para. 25; CJEU, C-557/12, Kone, EU:C:2014:1317, at para. 20; CJEU, C-453/99, Courage/Crehan, EU:C:2001:465, at para. 23; CJEU, C-295/04, Manfredi, EU:C:2006:461, at para. 39; see in this context also the Opinion of AG Van Gerven H.J. Banks \& Co Ltd v. British Coal Corp (C-128/92) EU:C:1994:130, which back in 1994 confirmed that the EU competition law provisions were directly enforceable by private parties.

7 CJEU, C-724/17, Skanksa Industrial Solutions, EU:C:2019:204, at para. 24 et seq.; CJEU, C-295/04, Manfredi, EU:C:2006:461, at para. 39; CJEU, C-199/11, Otis a.o., EU:C:2012:684, at para. 43.

8 CJEU, C-724/17, Skanksa Industrial Solutions, EU:C:2019:204, at para. 27.

9 The same reasoning applies to the determination of the circle of persons entitled to claim compensation for infringements of Art. 102 TFEU, see CJEU, C-637/17, Cogeco, EU:C:2019:263, at para. 38 et seq.; see also Kerse and Khan (2012), para 7.003.

10 Opinion of AG Wahl, Case C-724/17 Vantaan kaupunki v. Skanska Industrial Solutions, EU:C:2019:100.
} 
the "other side of the coin" of the circle of persons entitled to claim damages caused by infringements of competition law. ${ }^{11}$ Thus, liability for damages caused by anticompetitive behaviour directly follows from the wording of Art. 101 TFEU. ${ }^{12}$ At the core of this provision one finds "undertakings" as the addressees of the cartel prohibition. ${ }^{13}$ This finding provides an adequate ground ${ }^{14}$ to determine the circle of persons liable for harm caused by infringements of Art. 101 TFEU by declaring that the concept of undertaking shall define who bears the financial consequences of liability, such as fines or compensation. ${ }^{15}$

Due to the case-specific circumstances in Skanska, the Court was not obliged to fully explore the consequences of its finding. In Skanska, the Court "only" had to apply the economic continuity test, which forms part of the concept of undertaking, in order to assess liability. ${ }^{16}$ The result of the economic continuity test in this case was that the acquiring companies were to be held civilly liable. Consequently, it cannot be excluded that a company acquiring assets and liabilities of other companies involved in cartels and carrying on their commercial activities may, in addition to administrative fines, also be held liable for harm resulting from an agreement or practice prohibited under Art. 101 TFEU.

Although the CJEU in Skanska has somewhat further "Europeanised" the rules governing the right to seek compensation for harm resulting from anticompetitive behaviour, this judgment also provides for a significant insecurity as to the consequences of the judgment. ${ }^{17}$ It has to be pointed out that said insecurity is not solely confined to damages proceedings concerning infringements of Art. 101 TFEU. The CJEU has, in the meantime, applied the same reasoning to the determination of the circle of persons entitled to claim compensation for infringements of Art. 102 TFEU. $^{18}$

\subsection{Conceptual Backing}

In order to fully comprehend the CJEU's reasoning, it is worth turning to the Opinion of AG Wahl, upon which the Court heavily relied. ${ }^{19}$ According to AG Wahl, civil liability for damages caused by infringements of EU competition law is

\footnotetext{
11 Opinion AG Wahl, C-724/17, Skanska Industrial Solutions, EU:C:2019:100, at para. 61. For a concurring view see also Opinion of AG Pitruzzella, C-882/19, Sumal v. Mercedes Benz Trucks Espana, EU:C:2021:293, at para. 60 et seq.

12 This is also reflected in Art. 23 et seq. of Regulation 1/2003 as these provisions are directed at undertakings on which the Commission may impose fines, Kerse and Khan (2012), para. 7.003.

13 CJEU, C-724/17, Skanksa Industrial Solutions, EU:C:2019:204, at para. 29.

14 See on this the discussion in section 2.3 below.

15 See CJEU, C-434/13 P, Parker Hannifin Manufacturing, EU:C:2014:2456, at para. 39.

16 CJEU, C-724/17, Skanksa Industrial Solutions, EU:C:2019:204, at para. 38.

17 See for a thorough and critical assessment, Nagy (2019), p. 720. The author sees the judgment in Skanska as "part of the general tendency of "federalization' of competition law enforcement". See also in this regard Freund (2020), p. 496, where the "common constitutive conditions" of the right to damages for infringements of EU competition law are also analysed. See also Hennah (2019), p. 75 and Hornkohl (2021), p. 339 et seq.

18 CJEU, C-637/17, Cogeco, EU:C:2019:263, at 38 et seq. Wurmnest (2020), pp. 915, 924.

19 CJEU, C-724/17, Skanksa Industrial Solutions, EU:C:2019:204, at paras. 28, 45.
} 
to be determined in regard to the objectives pursued through claims for damages caused by anticompetitive behaviour. ${ }^{20}$ At a national level, the primary objective of cartel damages is to provide for compensation. ${ }^{21}$ Although the obligation to compensate victims can have a deterrent effect, most Member States' legal systems do not recognise this effect as a genuine purpose of cartel damages. ${ }^{22}$ This (traditional) understanding, however, changes in the context of European cartel damages, which are based on a violation of Art. 101(f) TFEU. ${ }^{23}$ The "constitutive conditions" 24 of the right to claim compensation are to be determined in accordance with Art. 101(f) TFEU rather than by national law - in contrast to the "rules governing the exercise", i.e. procedural rules of the right to claim compensation, which are to be determined by national law subject to the principles of equivalence and effectiveness. ${ }^{25}$ In the AG's understanding, private enforcement - and with it actions for damages - is an integral part of EU competition law enforcement. ${ }^{26}$ The bifurcated enforcement system pursues deterrence as its main objective, which in turn does not exclude that seeking compensation for harm caused by anticompetitive practices also serves a compensatory purpose. ${ }^{27}$ Therefore, public and private enforcement, the two branches making up the enforcement system, pursue a common objective, namely the deterrence of anticompetitive behaviour. ${ }^{28}$ As the objectives of those branches are identical; liability and thus the circle of those responsible for an infringement of competition law must be of equal meaning in public and private enforcement, i.e. the theory of an economic unit, and with it the notion of undertaking, are also to applied to private enforcement. ${ }^{29}$

\footnotetext{
${ }^{20}$ Opinion of AG Wahl, Case C-724/17 Vantaan kaupunki v. Skanska Industrial Solutions, EU:C:2019:100, at para. 48; Opinion of Van Gerven H.J. Banks \& Co Ltd v. British Coal Corp (C128/92) EU:C:1994:130, para. 44.

21 It is generally acknowledged that the compensation objective roots in the normative principle of corrective justice, see on this, Wils Wouter (2009), p. 3 et seq. and p. 16 et seq.; Jones (2015), p. 641 et seq. and p. 662; Hurni (2017), p. 65 et seq. and p. 113.

22 Opinion of AG Wahl, Case C-724/17 Vantaan kaupunki v. Skanska Industrial Solutions, EU:C:2019:100, para. 27.

23 Opinion of AG Wahl, Case C-724/17 Vantaan kaupunki v. Skanska Industrial Solutions, EU:C:2019:100, para. 28 .

24 Opinion of AG Wahl, Case C-724/17 Vantaan kaupunki v. Skanska Industrial Solutions, EU:C:2019:100, para. 40 et seq.

25 See on this Opinion of AG Kokott, C-435/18 Otis a.o. EU:C:2019:651, para. 44 et seq; see also Freund, p. 500 et seq.

26 Opinion of AG Wahl, Case C-724/17 Vantaan kaupunki v. Skanska Industrial Solutions, EU:C:2019:100, para. 80.

27 Opinion of AG Wahl, Case C-724/17 Vantaan kaupunki v. Skanska Industrial Solutions, EU:C:2019:100, para. 28 .

28 Opinion of AG Wahl, Case C-724/17 Vantaan kaupunki v. Skanska Industrial Solutions, EU:C:2019:100, para. 31 et seq.

29 Opinion of AG Wahl, Case C-724/17 Vantaan kaupunki v. Skanska Industrial Solutions, EU:C:2019:100, para. 81.
} 


\section{Adding a Further Supplement: The "Special Link" According to SUMAL (C-882/19)}

\subsection{Facts}

The Spanish company Sumal sued Mercedes Benz Trucks España, a Spanish subsidiary of the German Daimler AG, in Spain for damages. The grounds for the action relate to the so-called "truck cartel". ${ }^{30}$ In this case, the European Commission had sanctioned various truck manufacturers because of collusive arrangements on the pricing of trucks.

The first instance dismissed Sumal's action as inadmissible due to lack of standing of the Spanish subsidiary of Daimler. According to the court, the Spanish subsidiary could not be held liable for its infringing parent company. However, at the time of the proceedings, various judgments of other Spanish civil courts had already answered the question of liability differently. ${ }^{31}$ Hence, the court in question referred the case to the CJEU. The referral proceedings essentially revolved around the question of whether, within a group of companies, the (uninvolved) subsidiary can be held liable for the parent company's infringement. ${ }^{32}$

\subsection{Opinion of AG Pitruzzella}

\subsubsection{Main Reasoning}

In his Opinion, AG Pitruzzella addresses the matter by differentiating between two types of liability: downward and upward liability. ${ }^{33}$ The AG first examined the downward liability, pointing out that the case-law of the EU courts contains two distinct lines of reasoning. Each line provides for a different theoretical backing of liability for infringements of EU competition law. ${ }^{34}$

One line relies on the following assumption: the parent company, to which the unlawful conduct of its subsidiary is attributed, is held liable for an infringement of EU competition law, because it was able to determine its subsidiary's conduct on the market. ${ }^{35}$ The power to determine the market conduct suffices to impute in the form of a rebuttable presumption ${ }^{36}$ - liability for the conduct of an

\footnotetext{
${ }^{30}$ Commission Decision of 19 July 2016 relating to a proceeding under Article 101 of the Treaty on the Functioning of the European Union and Art. 53 of the EEA Agreement (Case AT.39824 - Trucks).

31 For an in-depth discussion of the Spanish case-law see Marcos (2020), p. 733.

32 See for an in-depth discussion Araujo Boyd (2020), pp. 25 et seq.

33 Opinion of AG Pitruzzella, Case C-882/19, Sumal v. Mercedes Benz Trucks Espana, EU:C:2021:293, at paras. 32 et seq. and 48 et seq. See also Kersting (2021), p. 126; Kersting and Otto (2021), p. 325.

34 Opinion of AG Pitruzzella, Case C-882/19, Sumal v. Mercedes Benz Trucks Espana, EU:C:2021:293, at para. 32 et seq.

35 Opinion of AG Pitruzzella, Case C-882/19, Sumal v. Mercedes Benz Trucks Espana, EU:C:2021:293, at para. 34. See also CJEU, Case C-516/15 P, Akzo Nobel, EU:C:2017:314, at para. 56.

36 See also CJEU, Case C-520/09, Arkema v. Commission, EU:C:2011:619, at para. 25; Scordamaglia (2010), p. 5 et seq. and p. 39.
} 
infringing subsidiary to a parent company. ${ }^{37}$ The parent is in a position to determine the market conduct of the infringing subsidiary and thus shoulders the financial responsibility. ${ }^{38}$ However, if the downward liability were the only way to impose liability, a subsidiary could not be held liable, as it, by definition, does not exercise a decisive influence over its parent company.

The other line of reasoning - the economic unit theory - is based on the idea that for assessing liability for an infringement of EU competition law the formal separation between two entities resulting from their separate legal personalities is not conclusive. The decisive test for liability to apply to the unity of several entities is that these entities act jointly on the affected market. ${ }^{39}$ These entities, which according to law might have independent personalities, then form one economic unit. And, in turn, it is for that unit to answer for that infringement. ${ }^{40}$ In this context and for the sake of clarity, it has to be pointed out that the concept of undertaking designates said economic unit that infringes competition law. ${ }^{41}$

In his Opinion, AG Pitruzzella opts for the second line of reasoning which provides the necessary background for his understanding of liability within an economic unit. He advocates that the recent jurisprudence determines liability in accordance with the economic unit theory. ${ }^{42}$ This understanding would enable the Court to apply liability in a downward manner, so-called "downward liability". 43 According to AG Pitruzzella, liability for an infringing parent company can be imputed to one of its subsidiaries if the latter's business is in some way necessary to give effect to the anticompetitive conduct. If that is the case, both form part of the same economic unit, i.e. the undertaking and can be held liable. This basically reflects the understanding of the second line of reasoning as pointed out above. It can also be concluded from AG Pitruzzella's findings that one group of companies may encompass more than one economic unit (see on this 3.2.1). ${ }^{44}$

However, not just any loose type of connection is sufficient. The subsidiary must have substantially contributed to the implementation of the anticompetitive conduct. $^{45}$ This would be the case if the subsidiary sold goods that are the subject

\footnotetext{
37 Opinion of AG Pitruzzella, Case C-882/19, Sumal v. Mercedes Benz Trucks Espana, EU:C:2021:293, at para. 43 .

38 Opinion of AG Pitruzzella, Case C-882/19, Sumal v. Mercedes Benz Trucks Espana, EU:C:2021:293, at para. 34.

39 See CJEU, Case C-217/05, Confederación Española de Empresarios de Estaciones de Servicio, EU:C:2006:784, at para. 41.

${ }^{40}$ CJEU, Case C-516/15 P, Akzo Nobel, EU:C:2017:314, at para. 49.

41 CJEU, C-724/17 Vantaan kaupunki v. Skanska Industrial Solutions EU:C:2019:204, at para. 37. In this regard see also Bauermeister (2021), p. 385.

42 Opinion of AG Pitruzzella, C-882/19, Sumal v. Mercedes Benz Trucks Espana, EU:C:2021:293, at para. 53.

43 Opinion of AG Pitruzzella, C-882/19, Sumal v. Mercedes Benz. Trucks Espana, EU:C:2021:293, at para. 48 et seq.

44 This finding is certainly not new, but, as it seems, often overlooked. See as an example Copper Plumbing Tubes (Case COMP/E-1/38.069) Commission Decision C(2004) 2826, at para. 564 et seq.

45 Opinion of AG Pitruzzella, C-882/19, Sumal v. Mercedes Benz Trucks Espana, EU:C:2021:293, at para. 57. For a dissenting opinion see Kersting and Otto (2021), p. 325 et seq.
} 
of the cartel or when a subsidiary directly deals with the damaged persons in a manner of customer services or an information role. ${ }^{46}$ It should, however, not be overlooked that it also has to be demonstrated that the parent company actually has decisive influence over its subsidiary. ${ }^{47}$

In essence and to sum up, according to AG Pitruzzella's reasoning, if damages are being sought from a subsidiary, two conditions have to be demonstrated: first, a decisive influence of the parent company over its subsidiary, and second, the activity of the targeted subsidiary must have contributed to the anticompetitive conduct. Therefore, liability for harm caused by the anticompetitive conduct cannot be imputed to a subsidiary if it is not active on the affected market.

\subsubsection{Conceptual Backing}

In regard to the conceptual backbone of his conclusion, AG Pitruzzella's Opinion in Sumal closely follows that of AG Wahl in Skanska. ${ }^{48}$ However, an additional (policy) layer can be found that further backs the deterrence objective of private enforcement. According to AG Pitruzzella, both private and public enforcement are indispensable means to ensure the effectiveness of general policy to combat anticompetitive practices. From this perspective, private enforcement not only pursues a restorative, i.e. compensatory function, but also has a deterrent function. And it is this latter function that justifies to confine deterrence as an independent objective of damages claims and hereby also contributes to above-mentioned policy. ${ }^{49}$ The more victims assert their rights, the more undertakings will be deterred from violating Art. 101(f) TFEU. The AG concludes that for victims of anticompetitive practices, the more the practical obstacles for seeking compensation are eliminated, the more private enforcement will act as a deterrent. ${ }^{50}$

\subsection{Judgment}

\subsubsection{Main Reasoning}

The concept of undertaking is the centrepiece of the CJEU's reasoning in Sumal. This concept ought to carry the same weight with regard to the imposition of administrative fines as well as with regard to actions for damages for infringement of EU competition law. ${ }^{51}$ In public enforcement, the concept of undertaking further designates the entity upon which a penalty for infringements of EU competition law

\footnotetext{
${ }^{46}$ High Court (UK), Vattenfall AB v. Prysmian SpA [2018] EWHC 1694 (Ch), at para. 72 et seq.

47 Opinion of AG Pitruzzella, C-882/19, Sumal v. Mercedes Benz. Trucks Espana, EU:C:2021:293, at para. 57.

48 See on this section 2.3 above.

49 Opinion of AG Pitruzzella, C-882/19, Sumal v. Mercedes Benz. Trucks Espana, EU:C:2021:293, at para. 67.

50 Opinion of AG Pitruzzella, C-882/19, Sumal v. Mercedes Benz. Trucks Espana, EU:C:2021:293, at para. 67 et seq.

51 CJEU, C-882/19, Sumal v. Mercedes Benz. Trucks Espana‘ EU:C:2021:800, at para. 38.
} 
is imposed. With regard to private enforcement, the CJEU further clarifies that the Damages Directive ${ }^{52}$ designates that the person liable for damages caused by infringements of competition law shall be the undertaking or association of undertakings which committed an infringement of competition law. ${ }^{53}$ The Court also recalls that the concept of "undertaking" differs from concepts such as "company" or "legal persons". 54 The meaning of undertaking is guided by the criterion of unitary conduct on the market and covers any entity engaged in an economic activity. ${ }^{55}$ In order to assess whether an entity forms part of an economic unit, it must - just as with the other constituents of the undertaking - pursue a "specific economic aim on a long-term basis". 56

According to the principal of personal responsibility, it is the infringing person who is to be held responsible in both private and public enforcement. ${ }^{57}$ As shown above, EU competition law does not differentiate between distinct persons in law, but solely takes account of the economic unit, which itself is the undertaking.

The CJEU, in essence and in line with AG Pitruzzella, differentiates between downward and upward liability - although it does not refer to the wording employed by the AG himself. In terms of upward liability, the Court recalls the settled caselaw, according to which the parent company might be held responsible for an infringement of one of its subsidiaries. ${ }^{58}$ This is in particular the case when the subsidiary does not determine independently its own market conduct but actually "executes" its parent's instructions. If that is the case, both the subsidiary and the parent form part of the same economic unit and thus belong to the same undertaking. ${ }^{59}$ However, if it is demonstrated that the subsidiary determines its own market conduct independently and thus does not act as merely an extension of its parent, the latter will generally not be held liable for its infringing subsidiary. ${ }^{60}$

Before discussing downward liability, the CJEU clarified that several legal entities within one corporate group may form separate undertakings. ${ }^{61}$ Therefore, liability cannot be perceived as a pure automatism that applies as soon as a parent company infringes EU competition law. A victim may not invoke liability of any

\footnotetext{
52 And in particular Art. 2(2) of the Directive 2014/104/EU of the European Parliament and of the Council of 26 November 2014 on certain rules governing actions for damages under national law for infringements of the competition law provisions of the Member States and of the European Union (OJ 2014 L 349, p. 1).

53 CJEU, C-882/19, Sumal v. Mercedes Benz Trucks Espana, EU:C:2021:800, at para. 40.

54 CJEU, C-882/19, Sumal v. Mercedes Benz. Trucks Espana, EU:C:2021:800, at para. 39.

55 CJEU, C-882/19, Sumal v. Mercedes Benz. Trucks Espana, EU:C:2021:800, at para. 41.

56 CJEU, C-882/19, Sumal v. Mercedes Benz. Trucks Espana, EU:C:2021:800, at para. 41.

57 CJEU, C-882/19, Sumal v. Mercedes Benz. Trucks Espana, EU:C:2021:800, at para. 42.

58 CJEU, C-882/19, Sumal v. Mercedes Benz Trucks Espana, EU:C:2021:800, at para. 43.

59 See to this CJEU, C-882/19, Sumal v. Mercedes Benz Trucks Espana, EU:C:2021:800, at para. 43.

${ }^{60}$ However, in practice and depending on the organisational ties between the parent company and its subsidiary, the "presumption of decisive influence" might apply. Although rebuttable, there exists few if not none case-law, where the presumption was successfully rebutted; see on this, Hornkohl (2021).

61 CJEU, C-882/19, Sumal v. Mercedes Benz Trucks Espana, EU:C:2021:800, at para. 45; see on this already Copper Plumbing Tubes (Case COMP/E-1/38.069) Commission Decision C(2004) 2826, at para. 564 et seq.
} 
subsidiary of a group of companies or conglomerate where different constituents of said group-structures are active in distinct economic fields, which themselves have no connection between them. ${ }^{62}$ In consequence, one parent company can be the head of several distinct undertakings; even though in law, all constituents of said undertakings belong to one group of companies. ${ }^{63}$

The Court then confirmed AG Pitruzella's understanding of the concept of undertaking, ${ }^{64}$ describing it as a "functional" concept. Therefore, it can only be determined through a case-by-case analysis if an undertaking exists. The decisive factor, however, is in every case that the constituents of the undertaking must act in conformity on the affected market as one economic unit, ${ }^{65}$ i.e. pursue a specific economic aim on a long-term basis. ${ }^{66}$ Applying the functional understanding to the issue of downward liability, a victim of an infringement of EU competition law does not have a remedy against all subsidiaries of an infringing parent company. ${ }^{67}$ Yet, the subsidiary might be held liable for damages caused by an infringement committed by another legal entity if both are part of the same economic unit and are, in consequence, part of the same undertaking. ${ }^{68}$ As a reminder, the infringer of EU competition law is always an undertaking. As long as a legal person or any other entity form part of an infringing undertaking, it has to shoulder liability for actions committed by other constituents (but not itself) of the undertaking as liability follows the principle of personal responsibility. ${ }^{69}$

The CJEU further clarified that the victim must prove that the distinct group entities form one undertaking by demonstrating that the following two criteria are met:

(i) economic, organisational, and legal links among the entities; ${ }^{70}$

(ii) a specific link between the economic activity of the envisaged subsidiary and the infringement committed by the parent company exists, ${ }^{71}$ i.e. it must be demonstrated that the infringement concerns the same products as those marketed by the parent company and its subsidiary. ${ }^{72}$

This exercise might turn out to be burdensome, as the subsidiary in national proceedings must dispose of all necessary means for the effective exercise of its rights of defence in order to prove that it does not form part of the undertaking.

\footnotetext{
62 CJEU, C-882/19, Sumal v. Mercedes Benz. Trucks Espana, EU:C:2021:800, at para. 45.

63 CJEU, C-882/19, Sumal v. Mercedes Benz. Trucks Espana, EU:C:2021:800, at para. 47.

64 Opinion of AG Pitruzzella, C-882/19, Sumal v. Mercedes Benz Trucks Espana, EU:C:2021:293, at para. 55 et seq.

65 Opinion of AG Pitruzzella, C-882/19, Sumal v. Mercedes Benz. Trucks Espana, EU:C:2021:293, at para. 55.

66 CJEU, C-882/19, Sumal v. Mercedes Benz. Trucks Espana, EU:C:2021:800, at para. 41.

67 CJEU, C-882/19, Sumal v. Mercedes Benz. Trucks Espana, EU:C:2021:800, at para. 46.

68 CJEU, C-882/19, Sumal v. Mercedes Benz Trucks Espana, EU:C:2021:800, at paras. 48, 50.

69 CJEU, C-882/19, Sumal v. Mercedes Benz. Trucks Espana, EU:C:2021:800, at para. 42 et seq.

70 CJEU, C-882/19, Sumal v. Mercedes Benz. Trucks Espana, EU:C:2021:800, at para. 51.

71 CJEU, C-882/19, Sumal v. Mercedes Benz. Trucks Espana, EU:C:2021:800, at para. 51.

72 See on this Röhrig (2021).
} 
However, the fact that the Commission, in its infringement decision, holds a parent company liable for an infringement of EU competition law, but does not address other group of companies, does not exclude that other constituents of the group also formed part of the same infringement and thus are to be regarded as belonging to the same undertaking. ${ }^{73}$ In essence, victims of anticompetitive practices may seek compensation for damages either against the parent company punished by the Commission for said practice or against a subsidiary of that company which is not referred to in that decision, given that those companies together constitute a single economic unit. ${ }^{74}$

\subsubsection{Conceptual Backing}

Just as in Skanksa, the CJEU relied on the AG's understanding of the role of private enforcement. However, unlike in Skanksa, the Court made its understanding even more pronounced. First, it recalled the already settled case-law that the effectiveness of Art. 101 TFEU would be jeopardized if it were not open to any individual to claim damages for anticompetitive harm. ${ }^{75}$ Such a right strengthens the working of EU competition rules, since it discourages agreements or practices - frequently covert - which are liable to restrict or distort competition, by contributing to the maintenance of effective competition. ${ }^{76}$ The Court stressed that the right to seek damages does not only serve the victim to obtain compensation for harm suffered but also contributes to the objective of dissuasion i.e. deterrence. Said objective also lies at the heart of the Commission's task, i.e. public enforcement. ${ }^{77}$ The right to seek damages is thus not only to be seen as a remedy for damages caused by anticompetitive practices but also to be regarded as a remedy for "indirect harm done to the structure and operation of the market, which was not able to reach full economic efficacy, in particular as regards benefits to the consumers concerned."78 Thus private and public enforcement are both an integral part of the enforcement of competition law. The enforcement system's main objective is to punish anticompetitive behaviour on the part of undertakings and to deter them from engaging in such conduct. ${ }^{79}$

As a consequence, the above-mentioned understanding of the objectives of private enforcement vests national courts with the power to review traditional concepts of tort law and related procedural rules regarding their conformity with the deterrence objective of actions brought for compensation for damages caused by anticompetitive conduct - just as might be the case regarding liability within a group of companies.

\footnotetext{
73 CJEU, C-882/19, Sumal v. Mercedes Benz. Trucks Espana, EU:C:2021:800, at para. 51.

74 CJEU, C-882/19, Sumal v. Mercedes Benz. Trucks Espana, EU:C:2021:800, at para. 67.

75 See already CJEU, C-453/99, Courage/Crehan, EU:C:2001:465, at para. 26.

76 See already CJEU, C-453/99, Courage/Crehan, EU:C:2001:465, at para. 27.

77 CJEU, C-882/19, Sumal v. Mercedes Benz. Trucks Espana, EU:C:2021:800, at para. 36.

78 CJEU, C-882/19, Sumal v. Mercedes Benz Trucks Espana, EU:C:2021:800, at para. 36.

79 CJEU, C-882/19, Sumal v. Mercedes Benz. Trucks Espana, EU:C:2021:800, at para. 37.
} 
However, before exploring the practical consequences of Sumal, a last critical observation has to be made. The CJEU's rhetoric seems to rely on the understanding that victims of anticompetitive behaviour have to be "mass mobilised" to effectively deter undertakings from infringing EU competition law - given that a causal relationship between the victim's harm and an agreement or practice prohibited under Art. 101 TFEU exists. ${ }^{80}$ It is noteworthy to contrast this understanding with the US Supreme Court's understanding of deterrence. In its judgment Illinois Brick Co. v. Illinois the Supreme Court reserved the right to sue for damages caused by violations of federal antitrust law to direct purchasers. ${ }^{81}$ Others, such as indirect purchasers who had only transacted with the direct purchaser, could not sue the infringer. ${ }^{82}$ This implies that victims of antitrust violations may not claim compensation, even though the cartel surcharge has been passed on to them. The Supreme Court argued that granting indirect purchasers standing to sue for damages would undermine deterrence as they were not in a position to sue as effectively as direct purchasers. ${ }^{83}$ At the bottom of the exclusion lies the rationale that, from a deterrence perspective, it is irrelevant whether the party receiving damages actually suffered any loss as long as the damages are enforced in an effective manner. ${ }^{84}$ Although, the legal and economic foundations for the exclusion of indirect purchasers are widely perceived as weak, ${ }^{85}$ the Supreme Court in Apple v. Pepper ${ }^{86}$ did not overrule Illinois Brick Co. v. Illinois. ${ }^{87}$ In Apple v. Pepper, the Supreme Court qualified customers who bought apps from Apple's App Store as direct purchasers of Apple, i.e. the consumers were deemed direct purchasers. ${ }^{88}$ Thus, Illinois Brick Co. v. Illinois did not apply and therefore, at least on a federal level, ${ }^{89}$ only direct customers of an alleged infringer can sue for damages.

In conclusion and in contrast to the CJEU's understanding, it is not the vast notion of standing to sue for damages that guarantees the effectiveness of private

\footnotetext{
${ }^{80}$ CJEU, C-882/19, Sumal v. Mercedes Benz. Trucks Espana, EU:C:2021:800, at para. 34; CJEU, C-435/ 18, Otis a.o, EU:C:2019:1069, at para. 30; CJEU, C-295/04, Manfredi, EU:C:2006:461, at para. 61; Opinion of AG Pitruzzella, C-882/19, Sumal v. Mercedes Benz Trucks Espana, EU:C:2021:293, at para. 33; see on this, Ellingsen (2019), p. 174 et seq.; Lombardi (2019), p. 66 et seq.

81 Illinois Brick Co. v. Illinois, 431 U.S. 720, 746 (1977).

82 Illinois Brick Co. v. Illinois, 431 U.S. 720, 746 (1977), at paras. 734-736, where it is hold that the victim was too far from the infringer in the chain of distribution to effectively claim compensation.

83 Illinois Brick Co. v. Illinois, 431 U.S. 720, 746 (1977), at paras. 730, 746 et seq. Even though indirect purchasers are denied standing on a federal level, this does not necessarily mean that they can not sue on state level, see on this California v. ARC Am. Corp., 490 U.S. 93, 105-106; Gavil (2014), p. 3 et seq. and p. 8; Moodaliyar (2018), p. 114 et seq.

84 See on this, Crane (2016), p. 357 et seq. and p. 358; see for the importance attached to the deterrence objective of claims for compensation of antitrust damages, Posner (2001), p. 266.

85 See Beneke (2019), p. 975 et seq. and p. 979 et seq.; Harrison (2019), p. 695 et seq. and p. 700 et seq.

86 Apple v. Pepper (2019) 139 S Ct 1514.

87 Benecke, supra note 85, p. 981.

88 See Apple v. Pepper (2019) 139 S Ct, 1518.

89 See supra note 83.
} 
Fig. 1 Liability of a subsidiary for its infringing parent

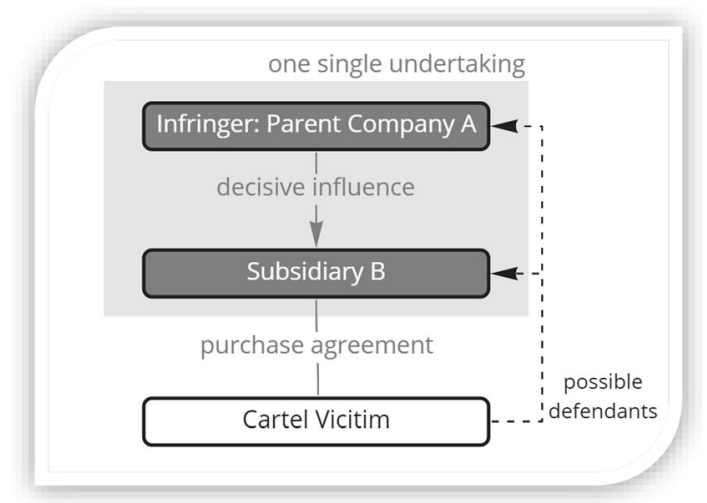

enforcement, but rather - and quite to the contrary - the exclusion of standing to sue of indirect purchasers, who often happen to be the final consumers. ${ }^{90}$

\section{Liability within a Group of Companies - Applying the CJEU's Reasoning Beyond Sumal}

The following exemplifies the Court's reasoning by examining, first, liability of an "innocent" subsidiary for its infringing parent company, and second, liability of an "innocent" subsidiary for an infringing subsidiary company.

\subsection{Liability of a Subsidiary for Its Infringing Parent}

To depict the liability of an "innocent" subsidiary for its infringing parent, one should imagine the following scenario: parent company A controls - in form a decisive influence - subsidiary B. If the parent company A engages in anticompetitive price agreements that affect the product market on which subsidiary B is active, cartel victims, which have bought the product from subsidiary B, can in principle bring an action for damages against parent company A as well as against subsidiary B. In regard to subsidiary B, both conditions are met: first, decisive influence of its parent company to form part of the same economic unit, and second, a material contribution to the infringement - the specific link (Fig. 1).

\subsection{Liability of a Subsidiary for Infringments of Other Group Companies}

The Court, and also the Opinion of AG Pitruzzella in Sumal, do not expressly provide guidance on the question of whether an "innocent" subsidiary might be held liable for an infringing subsidiary that belongs to the same group of companies. However, even though they do not deal with this scenario expressly, implicitly they give some guidance on how to assess the liability of an "innocent" subsidiary for an

\footnotetext{
90 See for a critical view on the rational of Illinois Brick Co. v. Illinois, Benecke, supra note 85, p. 981.
} 


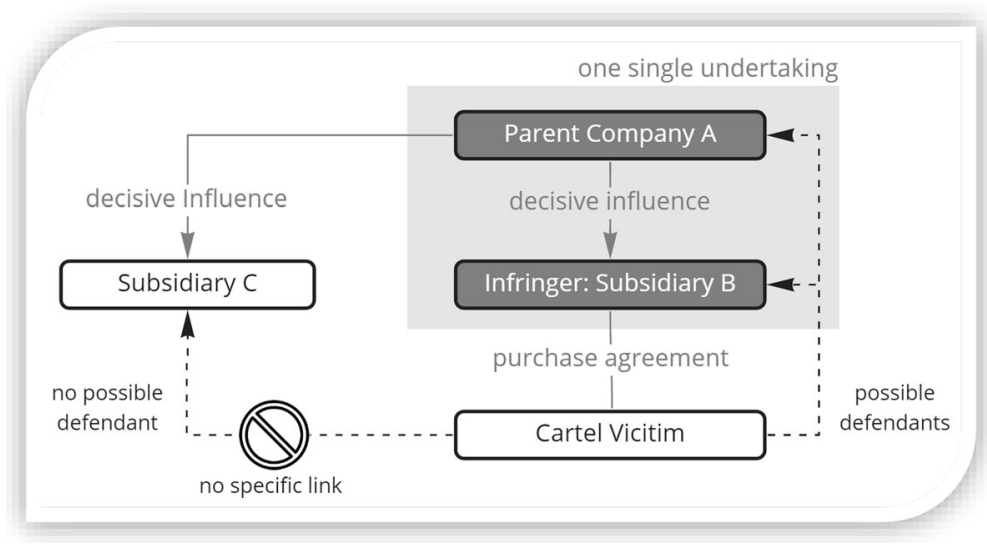

Fig. 2 Liability of a subsidiary not giving effect to an anticompetitive agreement

infringing subsidiary that pertains to the same group. To illustrate this guidance, one has to adjust the settings of the above-mentioned example as follows: it is no longer the parent company A which enters into an anticompetitive agreement, but subsidiary B. The parent company also exerts decisive influence over its subsidiary C. The infringement of subsidiary B, however, does not affect the product market of subsidiary C. In accordance with so-called "upward liability", a cartel victim may also seek damages from parent company A, as it exercised decisive influence over its infringing subsidiary B. In this case, parent company A and subsidiary B both form part of the same economic unit. This unit, however, does not encompass each entity controlled by the parent company A. Put differently: no specific link between the economic activity of subsidiary $\mathrm{C}$ and the infringment exists. Hence, the cartel victim might not seek compensation from subsidiary $\mathrm{C}$ as it does not participate in the infringement and thus is not part of the infringing undertaking, i.e. economic unit (Fig. 2).

However, if the product markets of subsidiary B and subsidiary $\mathrm{C}$ are not entirely different, compensation might also be sought from subsidiary $\mathrm{C}$. This might be the case - and by applying the reasoning of AG Pitruzzella's Opinion - if C gives, in a not insignificant manner, effect to the anticompetitive conduct, for example, by providing customer services regarding the cartel product sold by subsidiary B. In the words of the CJEU, the anticompetitive agreement concluded by the parent company must concern the same products as those marketed by the subsidiary. In this scenario subsidiary $\mathrm{C}$ helps to materialise the anticompetitive effects of the infringement and is - alongside with the infringing subsidiary B - under decisive influence of the parent company A. Thus, the conditions set by the Court in Sumal are met as there exist (i) economic, organisational, and legal links among the entities and (ii) a specific link. Therefore, parent company A and both subsidiaries B and $\mathrm{C}$ form part of the same undertaking and thus must shoulder the responsibility for the infringement (Fig. 3). 


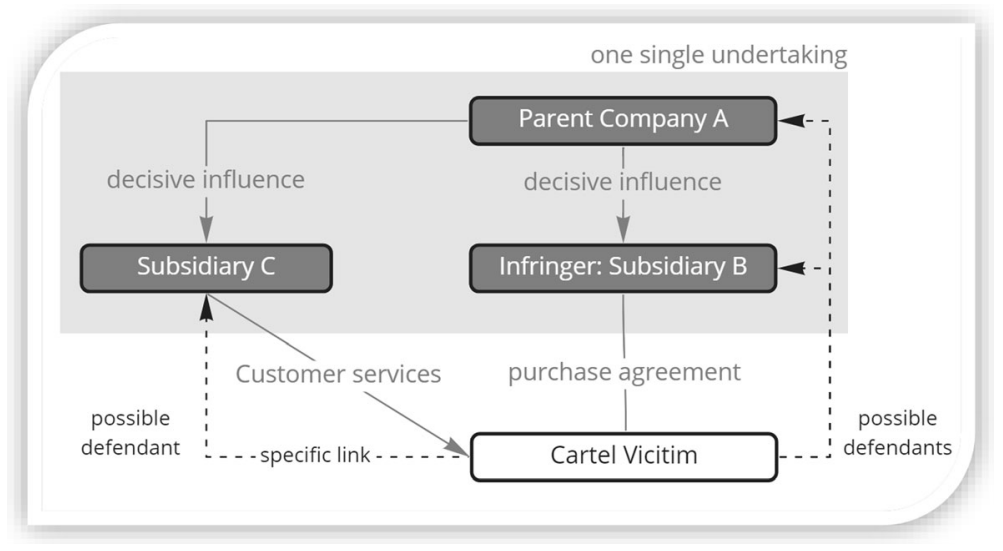

Fig. 3 Liability of a subsidiary giving effect to an anticompetitive agreement

\section{Conclusion}

The judgments in both Skanska and Sumal demonstrate the integral role assumed by private enforcement within the bifurcated enforcement system of EU competition law. Private enforcement ensures the full effectiveness of Art. 101 TFEU as well as Art. 102 TFEU. As the CJEU followed AG Pitruzzella's Opinion, victims which are domiciled outside of the Member State where the infringer is located are now placed in a significantly better position. ${ }^{91}$ As the undertaking is now to be seen as the proper target in private enforcement, cartel victims pursuing multinational enterprises will without doubt choose a jurisdiction in which a part of the relevant economic unit is domiciled; Arts. 4(1), 7(2) and 8(1) of Regulation 1215/2012 have now become even sharper tools in the claimant's hands. ${ }^{92}$ The judgment in Sumal decreases insecurities in regard to executing judgments in other Member States, ${ }^{93}$ which will result in lower translation costs, facilitate the bundling of claims by injured parties, and lower the risk of corporate restructuring and of transfers of assets within the economic unit in order to escape liability. ${ }^{94}$ Put differently, the judgment in Sumal significantly enhances the position of the victim and thereby ensures the full effectiveness of private enforcement.

It should also be highlighted that the Court in Sumal as well as AG Pitruzzella's Opinion heavily rely on Skanska and thereby corroborate the equal meaning of the

\footnotetext{
91 Opinion of AG Pitruzzella, C-882/19, Sumal v. Mercedes Benz. Trucks Espana, EU:C:2021:293, at para. 68.

92 Within the EU, claimants already benefit from a victim's friendly regime stipulated by the Recast Brussels Regulation. This can be exemplified by CJEU, C-352/13, CDC Hydrogen Peroxid, EU:C:2015:335 which provides for a generous interpretation of Art. 5(3) and Art. 6(1) of the predecessor to the Recast Brussels Regulation (Regulation 44/2001). See on this Hennah (2019), pp. 75, 79.

93 Opinion of AG Pitruzzella, C-882/19, Sumal v. Mercedes Benz Trucks Espana, EU:C:2021:293, at para. 68 .

94 See on this, Sousa (2021).
} 
concept of undertaking in public as well as in private enforcement. ${ }^{95}$ This entails as a consequence that liability for an infringement of EU competition law cannot be inferred by the simple reason of membership in a group of companies. ${ }^{96}$ However, the notion of undertaking is shaped through a somewhat divergent enforcement practice of the Commission and by case-law of the European courts that cannot always be called entirely stringent. This explains the - probably not entirely unwarranted - fears of a too far-reaching liability in private enforcement. Yet, the Court's understanding of the concept of undertaking shown in Sumal should at least partially dispel these fears as it requires that the subsidiary must in some way give effect to the anticompetitive conduct - the "specific link". Therefore, liability might not be ascribed to a subsidiary, which is not active - or only in a minor and negligible manner - on the affected market. The mere fact that the subsidiary is under the decisive influence of its infringing parent taken by itself does not justify the implementation of liability to a subsidiary for an infringement of its parent. Nor does the simple fact that if one subsidiary within a group of companies infringes competition law, this automatically results in liability for all group components. Yet, as with public enforcement, the notion of undertaking and hence what constitutes liability in competition law infringements is somewhat blurred. Therefore, the ramifications of the notion of undertaking applied to private enforcement, as stipulated by Skanska and now by Sumal, still have to be explored and will likely attract the CJEU's attention more than once.

Funding Open access funding provided by University of Zurich.

Open Access This article is licensed under a Creative Commons Attribution 4.0 International License, which permits use, sharing, adaptation, distribution and reproduction in any medium or format, as long as you give appropriate credit to the original author(s) and the source, provide a link to the Creative Commons licence, and indicate if changes were made. The images or other third party material in this article are included in the article's Creative Commons licence, unless indicated otherwise in a credit line to the material. If material is not included in the article's Creative Commons licence and your intended use is not permitted by statutory regulation or exceeds the permitted use, you will need to obtain permission directly from the copyright holder. To view a copy of this licence, visit http:// creativecommons.org/licenses/by/4.0/.

\section{References}

Araujo Boyd M (2020) Should children pay for their parent's sins? The Sumal preliminary reference. J Eur Competit Law Pract p. 25 et seq.

Bauermeister T (2021) Die Rs. Vantaan kaupunki/Skanska und Biogaran - Grundbausteine einer Sippenhaft? NZKart. p. 385

Beneke F (2019) U.S. Supreme Court: Klagebefugnis von iPhone-Nutzern in kartellrechtlichem Verfahren aufgrund exklusiven App-Verkaufs über Apple-Store - Apple v. Pepper. GRUR Int. p. 975 et seq. p. 979 et seqq.

Crane DA (2016) Compensation for antitrust violations: an economic perspective. Antitrust Bull 61(3). p. 357 et seq.

\footnotetext{
95 Opinion of AG Pitruzzella, C-882/19, Sumal v. Mercedes Benz. Trucks Espana, EU:C:2021:293, at para. 60 et seq.

96 Freund (2021), p. 738 et seq.
} 
Ellingsen HK (2019) Standing to enforce European Union law before national courts

Freund B (2020) Compensation for remote economic losses caused by infringements of Art. 101 TFEU Otis and Others v. Land Oberösterreich and Others (C-435/18). GRUR International. p. 500 et seq.

Freund B (2021) Reshaping liability - the concept of undertaking applied to private enforcement of EU competition law. GRUR International. p. 731 et seq.

Gavil AI (2014) Designing private rights of action for competition policy systems: the role of interdependence and the advantages of a sequential approach. In: Lowe P, Marquis M (eds) European competition law annual 2011: integrating public and private enforcement of competition law - implications for courts and agencies. London. p. 3 et seq.

Harrison JL (2019) After forty years of antitrust revision and Apple v. Pepper, what now Illinois Brick? William Mary Bus Law Review, Vol. 11. Issue 3, p. 695 et seq., p. 700 et seq.

Hennah J (2019) The role of "undertakings" in private law following Skanska, GCLR 2019, Vol. 12(2), p.75 et seq.

Hornkohl L (2021) The ECJ expands the presumption of decisive influence (C-595/18 P - Goldman Sachs v. Commission). http://competitionlawblog.kluwercompetitionlaw.com/2021/01/27/the-ecjexpands-the-presumption-of-decisive-influence-c\%E2\%80\%91595-18-p-goldman-sachs-vcommission/

Hurni B (2017) L'action civile en droit de la concurrence: étude du droit suisse à la lumière du droit comparé et du droit de l'Union européenne. Zurich

Jones A (2015) Competition law enforcement. In: Chalmers D, Arnull A (eds) The Oxford handbook of European Union law. Oxford. p. 641 et seq.

Kerse C, Khan N (2012) EU antitrust procedure, 6th edn. London

Kersting C (2021) Up- and down-stream liability within the economic unit: children liable for their parents! G.C.L.R. 14(3). p. 126 et seq.

Kersting C, Otto J (2021) "Auf- und absteigende" Haftung in der wirtschaftlichen Einheit: Kinder haften für ihre Eltern! NZKart. p. 325 et seq.

Laborde J-F (2021) Cartel damages actions in Europe: how courts have assessed cartel overcharges. September, Concurrences $N^{\circ} 3-2021$, Art. $N^{\circ} 102086$, p. 232 et seq.

Lombardi C (2019) Causation in competition law damages actions. Cambridge

Marcos F (2020) Primeros pronunciamientos de las Audiencias Provinciales sobre reclamaciones de danos causados por el cartel de camiones (I). https://almacendederecho.org/primerospronunciamientos-de-las-audiencias-provinciales-sobre-reclamaciones-de-danos-causados-por-elcartel-de-camiones-i

Moodaliyar K (2018) The direct and indirect purchaser's claim to competition law damages and the 'passing-on' defence in cartel cases. G.C.L.R. p. 114 et seq.

Nagy CI (2019) Has the time come to federalize private competition law? The autonomous concept of undertaking in the CJEU's ruling in case C-724/17 Vantaan Kaupunki v. Skanska Industrial Solutions Oy, NCC Industry Oy, Asfaltmix Oy. Maastricht Journal of European and Comparative Law. p. 720 et seq.

Posner RA (2001) Antitrust law. 2nd edn. Chicago

Röhrig M (2021) A topsy turvy world: children, watch after your parents - the Sumal judgment, top-down liability and its implications. https://hengeler-news.com/assets/articles/2021_11_BRX.pdf

Scordamaglia A (2010) Cartel proof, imputation and sanctioning in European law: reconciling effective enforcement and adequate protection of procedural guarantees. 7 Competition Law Review. p. 5 et seq.

Sousa FM (2021) Sumal (C-882/19): Skanska 2.0 - descending and lateral liability in the economic unit. EU Law Live, 16 April 2021

Wils Wouter P (2009) The relationship between public antitrust enforcement and private actions for damages. World Competition, vol. 32 no. 1. p. 3 et seq.

Wurmnest W (2020) Liability of "undertakings" in damages actions for breach of Articles 101, 102 TFEU: Skanska. 57(3) Common Market Law Review. p. 915 et seq.

\section{Cases}

Court of Justice of the European Union

CJEU, C-199/11, Otis a.o., EU:C:2012:684 
CJEU, C-453/99, Courage/Crehan, EU:C:2001:465

CJEU, C-295/04, Manfredi, EU:C:2006:461

CJEU, C-217/05, Confederación Española de Empresarios de Estaciones de Servicio, EU:C:2006:784

CJEU, C-520/09, Arkema v. Commission, EU:C:2011:619

CJEU, C-352/13, CDC Hydrogen Peroxid, EU:C:2015:335

CJEU, C-434/13 P, Parker Hannifin Manufacturing, EU:C:2014:2456

CJEU, C-516/15 P, Akzo Nobel, EU:C:2017:314

CJEU, C-724/17, Vantaan kaupunki v. Skanska Industrial Solutions, EU:C:2019:204

CJEU, C-637/17, Cogeco, EU:C:2019:263

CJEU, C-435/18, Otis a.o., EU:C:2019:1069

CJEU, C-882/19, Sumal v. Mercedes Benz.Trucks Espana‘ EU:C:2021:800

\section{Opinions - Advocate General}

Opinion of AG Pitruzzella, C-882/19 - Sumal v. Mercedes Benz Trucks Espana“ EU:C:2021:293

Opinion of AG Kokott, C-435/18 - Otis a.o., EU:C:2019:651

Opinion of AG Wahl, C-724/17 - Vantaan kaupunki v. Skanska Industrial Solutions, EU:C:2019:100

Opinion of AG Van Gerven, C-128/92 - H.J. Banks \& Co Ltd v. British Coal Corp, EU:C:1994:130

\section{Commission Decisions}

Commission Decision of 3 September 2004 relating to a proceeding pursuant to Article 81 of the EC Treaty and Article 53 of the EEA Agreement (Case COMP/E-1/38.069 - Copper Plumbing Tubes)

Commission Decision of 19 July 2016 relating to a proceeding under Article 101 of the Treaty on the Functioning of the European Union and Article 53 of the EEA Agreement (Case AT.39824 Trucks)

\section{High Court (UK)}

Vattenfall AB v. Prysmian SpA, [2018] EWHC 1694 (Ch)

\section{US Supreme Court}

Apple v. Pepper, (2019) 139 S Ct 1514

Illinois Brick Co. v. Illinois, 431 U.S. 720, 746 (1977)

Publisher's Note Springer Nature remains neutral with regard to jurisdictional claims in published maps and institutional affiliations. 